\title{
HPV and Methylation Indicators in Paired Tumor and Saliva in HNSCC
}

\author{
Josena K. Stephen ${ }^{1}$, Kang Mei Chen ${ }^{1}$, Meredith Mahan ${ }^{2}$, George Divine ${ }^{2}$, Tamer Ghanem ${ }^{1} \&$ Maria J. Worsham ${ }^{1}$ \\ ${ }^{1}$ Department of Otolaryngology/Head and Neck Research, Henry Ford Hospital, Detroit, USA \\ ${ }^{2}$ Department of Public Health Sciences, Henry Ford Hospital, Detroit, USA \\ Correspondence: Josena K. Stephen, M.D., Research Scientist, Department of Otolaryngology / Head and Neck \\ Research, Henry Ford Hospital, 1 Ford Place, 1D-06, Detroit, MI 48202, USA. Tel: 313-874-3487. Fax: \\ 313-874-6257. E-mail: jstephe2@hfhs.org
}

Received: July 26, 2013 Accepted: September 2, 2013 Online Published: September 10, 2013

doi:10.5539/cco.v2n2p42 URL: http://dx.doi.org/10.5539/cco.v2n2p42

\begin{abstract}
Human papilloma virus type 16 (HPV16) is a causative agent for some head and neck squamous cell carcinoma (HNSCC) and an independent risk factor for oropharyngeal SCC. The goal of this study was to examine HPV16 associated gene methylation in paired saliva and tumor DNA with assessment of the sensitivity, specificity, positive predictive, and negative predictive value for saliva HPV as a test for HNSCC. HPV16 status was determined by quantitative PCR (qPCR) in 35 primary HNSCC paired tumor and saliva specimens. Tumor cut points $\geq 0.03$ and $\geq 0.1$ and saliva cut points $>0$ and $\geq 0.001$ were used to classify results as HPV positive or negative. Aberrant methylation was determined by the methylation-specific multiplex ligation probe amplification (MS-MLPA) assay. The frequency of promoter hypermethylation in tumor samples was $66 \%$ $(23 / 35)$ versus $17 \%(6 / 35)$ in saliva. Two of 35 paired tumor and saliva samples had commonly methylated genes HPV and methylation were correlated for IGSF4 $(\mathrm{p}=0.01)$ in tumor samples (cut point $\geq 0.03$ ) and for ESR1 in saliva samples (cut point $>0$ ). Although the sensitivity of HPV detection in saliva was significantly reduced when saliva cut points were increased from $>0$ to $\geq 0.001$, the specificity and positive predictive values were $100 \%$ at saliva cut point of $\geq 0.001$, regardless of tumor cut points. Within clearly defined parameters, HPV detection in saliva DNA shows promise as a non invasive approach for tumor HPV status. Methylated genes detected in saliva may be useful in early detection and as potential predictive markers of HNSCC. Further confirmation and validation in larger cohorts is required.
\end{abstract}

Keywords: head and neck squamous cell cancer, HPV, methylation, paired tumor and saliva specimens

\section{Introduction}

Accurate and reliable stratification of head and neck squamous cell carcinoma (HNSCC) for prediction of outcomes has been challenging, mainly because of the numerous anatomic sites and sub-sites from which tumors can arise. HNSCC affect more than 500,000 people worldwide each year, accounting for 5\% of all malignancies, and a gradually increasing rate over the last three decades (Brockstein et al., 2004). In the United States, approximately 40,250 cases of oral cavity and pharynx HNSCC are expected in 2012 with an estimated 7,850 deaths (American Cancer Society [ACS], 2012).

For HNSCC, epidemiological and laboratory evidence now warrant the conclusion that the human papilloma virus (HPV) is a causative agent for some HNSCC (Gillison et al., 2000; Gillison \& Lowy, 2004a) and an independent risk factor for oropharyngeal SCC (OPSCC) (D'Souza et al., 2007; Chen et al., 2009; Ang et al., 2010). Molecular subtyping has shown that HPV positive HNSCC differ from HPV negative HNSCC in several ways. HPV positive HNSCC have genetic alterations that are indicative of HPV oncoprotein function (Gillison, 2004b) and are characterized by wild-type TP53 (Gillison et al., 2000; Hafkamp et al., 2003), wild-type CDKN2A (p16) (Licitra et al., 2006), and infrequent amplification of cyclin D (Ragin et al., 2006; Slebos et al., 2006; Smith et al., 2008), whereas the converse is true for HPV negative HNSCC. High-risk types of HPV encode E6 and E7, two viral oncoproteins that promote tumor progression by inactivating two well-characterized tumor suppressor proteins, TP53 and RB1, respectively (Scheffner, Werness, Huibregtse, Levine, \& Howley, 1990; Munger et al., 2004). 
While it is becoming more firmly established that HPV positive HNSCC have better survival outcomes than HPV negative HNSCC (Gillison et al., 2000; SR Schwartz, Yueh, McDougall, Daling, \& SM Schwartz, 2001; Weinberger et al., 2006; Ang et al., 2010; Worsham et al., 2013b), believed to be because of better response to chemo radiation (Fakhry et al., 2008), the underlying mechanism for these improved prognosis outcomes remains underexplored. Epigenetic events of promoter hypermethylation represent important tumor-specific markers occurring early in tumor progression. Our group has demonstrated using high-throughput methods, the contribution of both genetic (Worsham et al., 2003; Worsham et al., 2006b) and epigenetic events (Maruya et al., 2004), often working together (Worsham et al., 2006a), in the development and progression of HNSCC. A recent study of over 27,000 CpGs, while supporting differential DNA methylation in HPV-associated HNSCC also indicted epigenetic modulation of signal transduction pathways (Worsham, Chen, Ghanem, Stephen, \& Divine, 2013a). Also, studies are beginning to establish a mechanistic role for promoter methylation with improved survival outcomes in HPV positive HNSCC. Gubanova et al. (2012) showed that promoter hypermethylation and concordant low $S M G-1$ expression correlated not only with HPV positive status and improved patient survival, but also enhanced response to radio therapy in HPV-positive HNSCC cell lines.

Epigenetic alterations identified in saliva and cancerous lesions with biomarker potential would have high clinical significance in risk assessment and early detection. The goal of this study was to examine the utility of saliva as a non-invasive approach to detect high risk HPV and associated aberrantly methylated genes in paired saliva and tumor HNSCC.

\section{Materials and Methods}

\subsection{Cohort}

The study cohort consisted of 35 HNSCC with saliva and tumor tissue from the same patient. Sites in the head and neck included oral cavity (OC), oropharynx (OP), hypopharynx (HP), larynx and other site (consisting of nasopharynx, paranasal sinuses, neck mass, head and neck skin). Patients diagnosed within the Henry Ford Health System with both saliva and tumor tissue collected between 2006 and 2007 were included in the study. Risk factor information was obtained from patient questionnaires and electronic medical records.

This study was approved by the Henry Ford Health System Institutional Review Board committee and informed consent was obtained from all enrolled subjects.

\subsection{DNA Extraction and HPV Detection}

Two milliliters of saliva were collected from each study subject in Oragene DNA kits (DNA Genotek Inc, Ontario, Canada), and saliva DNA was extracted according to the manufacturer's instructions.

Whole 5 micron sections or microdissected HNSCC lesions were processed for DNA extraction as previously described (Raju et al., 2006). Tumor and saliva HPV DNA was determined using quantitative real time PCR (qPCR) (Worsham et al., 2013b; Chen et al., 2013; Stephen et al., 2013; Stephen et al., 2012). Tumor cut points of $\geq 0.03$ and $\geq 0.1$ and saliva cut points of $>0$ and $\geq 0.001$ were used to classify results as HPV positive or negative (Worsham et al., 2013b; Chen et al., 2013; Stephen et al., 2013; Stephen et al., 2012).

\subsection{Methylation-Specific Multiplex Ligation-dependent Probe Amplification (MS-MLPA) Assay}

Archival tissue and saliva DNA were interrogated for methylation status using the multi-gene methylation-specific multiplex ligation-dependent probe amplification (MS-MLPA) assay. MS-MLPA (Worsham et al., 2006a; Chen et al., 2007), a modification of the conventional MLPA assay (Schouten et al., 2002) allows for the simultaneous detection of changes in methylation status as well as copy number changes of approximately 41 different DNA sequences in a single reaction requiring only 20ng of human DNA.

Briefly, the MS-MLPA panel in the presence of HhaI detects aberrant promoter hypermethylation by taking advantage of a $H h a \mathrm{I}$ site in the gene probes of interest. The control gene probes, without a HhaI site, serve as undigested controls. A normal control DNA sample will generate 41 individual peaks for all probes in the absence of HhaI and 15 separate peaks in the presence of HhaI (Stephen et al. 2010). Normal controls for methylation assays are run using DNA from paraffin-embdedded squamous epithelium from individuals with no evidence of cancer.

\subsection{Gene Probe Panels}

The 41 gene probe panel (ME001B, www. mlpa.com) used in this cohort interrogates 38 unique genes implicated in cancer (24 tumor suppressor genes) for methylation status in two separate reactions (one in the absence of the methyl-sensitive enzyme $H h a \mathrm{I}$ and one in the presence of the $H h a \mathrm{I}$ enzyme). There are two probes each for $M L H 1, R A S S F 1$ and BRCA2, and a normal control DNA sample will generate 41 individual peaks in the absence 
of $H h a \mathrm{I}$ and 15 individual peaks in the presence of HhaI.

\subsection{Statistical Analysis}

Fisher's exact tests were used to examine the association between HPV and each gene as well as age, gender, smoking, race, site and stage in tumor and saliva samples. Wilcoxon Mann-Whitney tests were used to compare continuous variables between groups. The sensitivity, specificity, positive predictive value, and negative predictive value of saliva results were calculated using $2 \times 2$ tables. Statistical significance was set at $\mathrm{p}<0.05$. All data were analyzed using SAS 9.2.

\section{Results}

The median age of the cohort was 56 years (range 22 to 81 years). There were 26 males and 9 females. The majority of the biopsies were from the larynx (13/35) followed by the oropharynx (7/35), other site $(6 / 35$, includes nasopharynx, paranasal sinuses, neck mass, head and neck skin), oral cavity (5/35), and hypopharynx $(4 / 35)$.

\section{$3.1 \mathrm{HPV}$}

In this study HPV positivity cut points for saliva were set at $>0$ or $\geq 0.001$ and for tumor at $\geq 0.03$ or $\geq 0.1$. The criteria for cut points of $>0$ or $\geq 0.001$ for saliva and $\geq 0.1$ for tumor were set by Zhao et al. (2005) to measure sensitivity and specificity of HPV detection in matched tumor and saliva specimens. The tumor cut point of $\geq 0.03$ was previously determined by our group (Stephen et al., 2012). HPV data was not available for 4 of 35 tumor samples. Their corresponding saliva samples were HPV negative at cut point $\geq 0.001$, but at cut point $>0$, one saliva sample was HPV positive. For saliva, 12/35 samples at cut point $>0$ and $3 / 35$ samples at cut point $\geq 0.001$ were HPV positive. Of the 31 tumor samples with HPV data, 10 samples at cut point $\geq 0.03$ and 8 at cut point $\geq 0.1$ were HPV positive. Of the 35 cases, at tumor cut point of $\geq 0.03$ and saliva cut point of $>0$, seven were positive for HPV in the saliva and tumor from the same patient, decreasing to 6 matched pairs when the tumor HPV cut point was raised to $\geq 0.1$. However, when the saliva cut point was raised to $\geq 0.001$, this decreased to three cases for both tumor and saliva, regardless of tumor cut point. Of the 35 matched cases, 17 had agreement for lack of HPV in saliva and tumor regardless of cut points. This was increased to 21 matched cases at saliva cut point of $\geq 0.001$.

There were a few discordances between the saliva and tumor samples but only at saliva cut point of $>0$, with 4 and 5 discordant cases at tumor cut point $\geq 0.03$ and $\geq 0.1$, respectively. The latter is reflected in the sensitivity, specificity, positive predictive value, and negative predictive value for saliva HPV. At saliva HPV cut point of $\geq 0.001$, specificity and positive predictive values were $100 \%$ regardless of tumor cut points; however, sensitivity was low (Table 1). The sensitivity of HPV detection in saliva at tumor cut point $\geq 0.03$ went from $70 \%$ to $30 \%$ at saliva cut points $>0$ and $\geq 0.001$, respectively. Similarly at tumor cut point $\geq 0.1$, the sensitivity decreased from $75 \%$ to $37.5 \%$ at saliva cut points $>0$ and $\geq 0.001$, respectively (Table 1).

Table 1 . Sensitivity and specificity

\begin{tabular}{lllll}
\hline & Sensitivity & Specificity & PPV & NPV \\
\hline Tumor $\geq 0.03$ vs saliva $>0$ & $70.0 \%$ & $81.0 \%$ & $63.6 \%$ & $85.0 \%$ \\
Tumor $\geq 0.03$ vs saliva $\geq 0.001$ & $30.0 \%$ & $100 \%$ & $100 \%$ & $75.0 \%$ \\
Tumor $\geq 0.1$ vs saliva $>0$ & $75.0 \%$ & $78.3 \%$ & $54.6 \%$ & $90.0 \%$ \\
Tumor $\geq 0.1$ vs saliva $\geq 0.001$ & $37.5 \%$ & $100.0 \%$ & $100 \%$ & $82.1 \%$ \\
\hline
\end{tabular}

$\mathrm{PPV}$ - positive predictive value; NPV - negative predictive value

Older individuals (over 61 years) with HNSCC were more likely to be HPV negative ( $p=0.009$ at a tumor HPV cut point of $\geq 0.03$ (Table 2), whereas oropharyngeal tumors were more likely to be HPV positive $(\mathrm{p}=0.015$ ) at a saliva cut point of $\geq 0.001$ (Table 3). 
Table 2. Tumor HPV and demographics at tumor cut point $\geq 0.03$

\begin{tabular}{|c|c|c|c|c|}
\hline Variable & Response & Negative $(T)(N=21)$ & Positive (T) (N= 10) & p-value \\
\hline Age & & $61.0 \pm 17.8$ & $52.5 \pm 12.5$ & 0.009 \\
\hline \multirow[t]{2}{*}{ Gender } & Female & $7(33 \%)$ & $1(10 \%)$ & 0.222 \\
\hline & Male & $14(67 \%)$ & $9(90 \%)$ & \\
\hline \multirow[t]{3}{*}{ Smoking } & Current & $12(60 \%)$ & $4(40 \%)$ & 0.312 \\
\hline & Never & $2(10 \%)$ & $0(0 \%)$ & \\
\hline & Past & $6(30 \%)$ & $6(60 \%)$ & \\
\hline \multirow[t]{2}{*}{ Race } & AA & $5(24 \%)$ & $4(44 \%)$ & 0.389 \\
\hline & $\mathrm{CA}$ & $16(76 \%)$ & $5(56 \%)$ & \\
\hline \multirow[t]{5}{*}{ Site } & HP & $2(10 \%)$ & $0(0 \%)$ & 0.701 \\
\hline & Larynx & $10(48 \%)$ & $3(30 \%)$ & \\
\hline & $\mathrm{OC}$ & $2(10 \%)$ & $1(10 \%)$ & \\
\hline & OP & $4(19 \%)$ & $3(30 \%)$ & \\
\hline & Other & $3(14 \%)$ & $3(30 \%)$ & \\
\hline \multirow[t]{5}{*}{ Stage } & 0 & $0(0 \%)$ & $1(10 \%)$ & 0.397 \\
\hline & 1 & $7(33 \%)$ & $1(10 \%)$ & \\
\hline & 2 & $3(14 \%)$ & $1(10 \%)$ & \\
\hline & 3 & $3(14 \%)$ & $1(10 \%)$ & \\
\hline & 4 & $8(38 \%)$ & $6(60 \%)$ & \\
\hline
\end{tabular}

T - Tumor, AA - African American, CA - Caucasian American, HP - Hypopharynx, OC - Oral cavity, OP - Oropharynx

Table 3. Saliva HPV and demographics at saliva cut point $>0.001$

\begin{tabular}{|c|c|c|c|c|}
\hline Variable & Response & Negative $(\mathrm{S})(\mathrm{N}=32)$ & Positive $(\mathrm{S})(\mathrm{N}=3)$ & p-value \\
\hline Age & & $56.7 \pm 13.3$ & $62.0 \pm 13.1$ & 0.599 \\
\hline \multirow[t]{2}{*}{ Gender } & Female & $9(28 \%)$ & $0(0 \%)$ & 0.553 \\
\hline & Male & $23(72 \%)$ & $3(100 \%)$ & \\
\hline \multirow{3}{*}{ Smoking } & Current & $17(55 \%)$ & $1(33 \%)$ & 0.668 \\
\hline & Never & $3(10 \%)$ & $0(0 \%)$ & \\
\hline & Past & $11(35 \%)$ & $2(67 \%)$ & \\
\hline \multirow[t]{2}{*}{ Race } & $\mathrm{AA}$ & $11(34 \%)$ & $0(0 \%)$ & 1.000 \\
\hline & $\mathrm{CA}$ & $21(66 \%)$ & $2(100 \%)$ & \\
\hline \multirow[t]{5}{*}{ Site $^{\mathrm{a}}$} & HP & $4(13 \%)$ & $0(0 \%)$ & 0.015 \\
\hline & Larynx & $13(41 \%)$ & $0(0 \%)$ & \\
\hline & $\mathrm{OC}$ & $5(16 \%)$ & $0(0 \%)$ & \\
\hline & $\mathrm{OP}$ & $4(13 \%)$ & $3(100 \%)$ & \\
\hline & Other & $6(19 \%)$ & $0(0 \%)$ & \\
\hline \multirow[t]{5}{*}{ Stage } & 0 & $1(3 \%)$ & $0(0 \%)$ & 0.626 \\
\hline & 1 & $8(25 \%)$ & $0(0 \%)$ & \\
\hline & 2 & $6(19 \%)$ & $0(0 \%)$ & \\
\hline & 3 & $4(13 \%)$ & $0(0 \%)$ & \\
\hline & 4 & $13(41 \%)$ & $3(100 \%)$ & \\
\hline
\end{tabular}

S - Saliva, AA - African American, CA - Caucasian American, HP - Hypopharynx, OC - Oral cavity, OP - Oropharynx ${ }^{\text {a }}$ Site differs significantly between the saliva HPV groups. All 3 of the HPV positive patients have OP sites. 


\subsection{Methylation}

The frequency of promoter hypermethylation in tumor samples was $66 \%(23 / 35)$ as compared to $17 \%(6 / 35)$ in saliva (Supplemental Table 1). The most frequently methylated genes in saliva samples included TIMP3, $C D K N 2 B$, and $E S R 1$ (3/6) followed by $A P C, D A P K 1$ and $I G S F 4(2 / 6)$. The most frequently methylated genes in tumor cases included RARB -10/23, APC - 9/23, TIMP3 and CDKN2B - 7/23, CDKN2A and IGSF4 - 5/23 tumor samples. Two (6\%) of 35 paired cases had methylated genes in common. $A P C$ was methylated in tumor and saliva from Case 31, both of which were HPV negative. TIMP3, CDKN2B, ESR1 and IGSF4 were methylated in saliva and tumor in Case 93, which was HPV16 positive only in the tumor sample. Of the remaining 33 cases, 10 $(29 \%)$ had agreement for lack of methylation in saliva and tumor.

\subsection{Methylation and HPV}

In the tumor samples, at HPV cut point of $\geq 0.03$, methylation of $R A R B(\mathrm{p}=0.04), C D K N 2 B(\mathrm{p}=0.027)$ and $I G S F 4$ $(\mathrm{p}=0.027)$ was associated with being HPV positive; only IGSF4 $(\mathrm{p}=0.01)$ was associated with HPV positive status at tumor cut point $\geq 0.1$. In saliva samples, methylation of ESR1 correlated with HPV positive status $(\mathrm{p}=0.034$ ) but only at cut point $>0$. There was no association between HPV status and methylation in saliva at cut point $\geq 0.001$.

\section{Discussion}

Alterations in gene sequences, expression levels and protein structure or function have been associated with every type of cancer. These molecular markers can be useful in detecting cancer, determining prognosis and monitoring disease progression or therapeutic response. DNA-based tumor markers usually have distinct characteristics rendering them attractive targets for molecular diagnosis of cancer in body fluids (Goessl, Muller, Straub, \& Miller, 2002). Body fluids used for early detection of cancer include sputum for lung cancer (Palmisano et al., 2000; Belinsky et al., 2006), urine for urologic tumors (Hoque et al., 2004), and breast fluid (Lee et al., 2004). Currently for head and neck cancers there is no routine early detection test even though these cancers are often curable if found early. There is, however, evidence that oral examination screenings for early detection of high-risk populations for HNSCC may be cost effective (Speight et al., 2006). HPV detection in saliva DNA presents an added advantage in screening for HNSCC as it is readily available and noninvasive. Also, its feasibility as a screening tool for high-risk individuals for HNSCC is supported by recent studies (Zhao et al., 2005; Chen et al., 2013).

A study from our group examining saliva from HNSCC patients and normal controls demonstrated that saliva gene-based algorithms can differentiate patients from normal controls (Sethi, Benninger, Lu, Havard, \& Worsham, 2009). In particular a gain in copy number of PMAIP1 alone or in combination with PTPN1 in saliva can differentiate HNSCC cases from normal controls with a high degree of sensitivity and specificity. This suggests that saliva can represent tumor-associated genetic alterations, making it a useful screening tool for detection and monitoring of head and neck cancers. A study by Carvalho et al. (2011) confirmed the presence of a panel of known hypermethylated genes in HNSCC in the saliva of HNSCC patients. They also found that gene hypermethylation is associated with local recurrence and poorer overall survival. In a follow up study, TIMP3 methylation alone was associated with local recurrence-free survival in HNSCC, indicating its possible use as a salivary rinse biomarker for HNSCC recurrence (Sun et al., 2012). We found TIMP3 to be frequently methylated in saliva (3/6) and tumor (7/23) samples. TIMP3 was also methylated in the paired saliva and tumor of one case. Other studies on salivary rinses by Rettori et al.(2013) and Kaur et al.(2010) have found that different ethnic cohorts from different geographic regions also have very similar gene hypermethylation patterns. This suggests that detection of methylated genes in salivary rinses could constitute a specific and robust marker that could be applied across geographic populations.

In our current study the frequency of promoter methylation was greater in the tumor samples when compared to saliva $(66 \%$ vs $17 \%)$. We found that for 10 cases the primary tumor and corresponding saliva were concordant for lack of methylation. Of the 23 cases in which the primary tumor was methylated only 4 (17\%) presented with methylation of 1 or more genes in the corresponding saliva. This may be due to dilution effects of normal (and presumed nonmethylated) genomes present in saliva from normal mucosa (Carvalho et al., 2008). It is also possible that the methylation rate of each specific gene could vary because of differences in the cohort composition among different studies, specifically tumor localization (Rettori et al., 2013). Also, different methods of specimen collection may affect the quantity of altered cells in saliva. Our saliva samples were obtained as spit saliva. However, it has been shown that hypermethylation patterns in saliva collected with or without exfoliating brush do not differ (Sun et al., 2012).

Saliva specimens in 2 cases displayed gene methylation lacking in the corresponding primary tumor. Some 
reasons for this might include 1) spurious results in saliva, 2) methylated genes comprising only a minor tumor clone without or insufficient representation in the tumor DNA, or 3) methylation unrelated to the tumor.

Several studies have shown the presence of HPV16 in saliva of HNSCC patients (Smith et al., 2004; Zhao et al., 2005). A recent study from our group found that the overall prevalence of HPV in saliva was significantly different between control subjects, screening subjects without head and neck cancer, and patients with head and neck cancer (Chen et al., 2013). At cut point $>0$, each group had an overall HPV prevalence of over $5 \%$, with a higher prevalence of $30.8 \%$ in the HNC patient group. At cut point $>0.001$, the prevalence was $0 \%$ in the control, $1.2 \%$ in the screening, and $16.7 \%$ in the HNC group. HPV prevalence in the HNC group at both cut points was different across sites $(<0.001)$ and significantly higher in the oropharynx $(\mathrm{OP})$ than larynx or site as other after Hochberg's adjustment (Chen et al., 2013), and support the findings of our current study that non-OP sites are more likely to be HPV negative than OP sites. This corresponds to studies of tumor tissue where the frequency of HPV infection is significantly higher in OP than in other sites of the head and neck including HP, larynx, and OC (Kreimer et al., 2005; Dayyani et al., 2010; Stephen et al., 2013). Chuang et al. (2008) correlated the presence of HPV16 in surveillance salivary rinses with disease progression in HNSCC. Similar to pap smear screening performed for early detection of cervical cancers (Sankaranarayanan, Budukh, \& Rajkumar, 2001), HPV detection in saliva DNA could help with early detection of HNSCC, especially in OPSCC, with a distinct advantage of a non-invasive approach.

In our current study, we found HPV in $32 \%(10 / 31)$ and $26 \%(8 / 31)$ of our tumor samples at cut point $\geq 0.03$ and $\geq 0.1$, respectively. In the saliva, HPV was present in $34 \%(12 / 35)$ and $9 \%(3 / 35)$ at cut point $>0$ and $\geq 0.001$, respectively. As saliva cut points for HPV increased from $>0$ to $\geq 0.001$, the sensitivity was significantly reduced regardless of tumor cut points (70\% to $30 \%$ at tumor cut point $\geq 0.03$ and $75 \%$ to $37.5 \%$ at tumor cut point of $\geq 0.1$ ). A limitation of this study was the relatively small samples size of only 35 paired cases. Regardless, at saliva cut point $>0$ and tumor cut point $\geq 0.1$, positive predictive values (PPV) and negative predictive values (NPV) in our study were comparable to the Zhao et al. study (2005) of 92 matched saliva and tumor cases (PPV of $54.6 \%$ in our study vs $53.3 \%$ and NPV of $90 \%$ in our study vs $80.6 \%$ ).

Promoter hypermethylation in HNSCC has been reported for numerous tumor suppressor genes. In this study, IGSF4, ESR1, $C D K N 2 B$ and RARB methylation were significantly associated with HPV positive status at various tumor and saliva cut points. In the tumor samples, at HPV cut point of $\geq 0.03$, methylation of $R A R B(\mathrm{p}=0.04)$, $C D K N 2 B(\mathrm{p}=0.027)$ and IGSF4 $(\mathrm{p}=0.027)$ was associated with being HPV positive; only IGSF4 $(\mathrm{p}=0.01)$ was associated with HPV positive status at tumor cut point $\geq 0.1$. In saliva samples, methylation of $E S R 1$ correlated with HPV positive status $(\mathrm{p}=0.034)$ but only at cut point $>0$. There was no association between HPV status and methylation in saliva at cut point $\geq 0.001$. IGSF4 is a novel immunoglobulin-like intercellular adhesion molecule first characterized as a tumor suppressor of non-small cell lung cancer and termed TSLC1 (Murakami et al., 1998; Kuramochi et al., 2001), in which silencing was primarily achieved by allelic loss and promoter methylation. IGSF4 is located at the region of 11q23.2 and spans more than 300 kilobases (Murakami et al., 1998). Promoter hypermethylation of IGSF4 has been reported in nasopharyngeal carcinomas (Hui et al., 2003). In HNSCC, promoter hypermethylation of IGSF4 is a primary as well as a disease progression event, indicating complete abrogation of tumor suppressor function (Worsham et al., 2006). IGSF4 hypermethylation is also a highly frequent event in cervical cancers where epigenetic silencing of IGSF4 has been implicated in the progression from high-risk HPV-containing, high-grade CIN lesions to invasive cervical cancer (Steenbergen et al., 2004). Furthermore, IGSF4 silencing was accompanied by complete loss or significant decrease of IGSF4 mRNA expression in these cell lines. In esophageal squamous cell carcinoma (ESCC), loss of IGSF4 protein expression as a consequence of promoter hypermethylation, a late stage event in ESCC carcinogenesis, has been implicated in invasion and metastasis and aggressive tumor behavior through the disruption of cell-cell interactions (Ito et al., 2003). Additionally, IGSF4 may offer a promising new therapeutic target in ESCC because expression can be restored by a demethylating agent (Ito et al., 2003).

ESR1, located at 6q25.1, is important for hormone binding, DNA binding, and activation of transcription (Ponglikitmongkol, Green, \& Chambon, 1988). ESRI has metastasis-suppressor properties in breast cancer cells (Garcia, Derocq, Freiss, Rochefort, 1992), suggesting a tumor-suppressor role for ESRI (Issa et al., 1994). Methylation of $\mathrm{CpG}$ sites in the ESR1 promoter, with concordant loss or downregulation of ESR1 expression, is the primary mechanism in prostate cancer (Li et al., 2000). ESRI is methylated in Barrett's metaplastic and dysplastic samples as well as in some adenocarcinoma samples, suggesting that DNA hypermethylation is an early epigenetic event in the progression of esophageal adenocarcinomas (EAC) (Eads et al., 2000). A previous study by our group on laryngeal squamous cell carcinomas found that aberrant methylation of ESRl was an independent predictor of late stage diagnosis (Stephen et al., 2010). ESRI also exhibits age-dependent 
methylation in colon mucosa (Issa et al., 1994), the cardiovascular system (Post et al., 1999), ulcerative colitis (Issa et al., 2001), and prostate cancer, suggesting that ESR1 may be involved in age-dependent increase in cancer incidence.

Cyclin-dependent kinase inhibitor 2B (CDKN2B), also known as $p 15$, inhibits $\mathrm{CDK} 4$ and regulates cell growth by controlling cell cycle G1 progression. Inactivation of $C D K N 2 B$ gene at the genomic and epigenetic level is a frequent event in human oral SCCs (Yeh et al., 2003) and in HNSCC (Shintani et al., 2001; Worsham et al., 2003; Worsham et al., 2006). In precancerous oral tissues and lesions of the head and neck (Shintani et al., 2001; Worsham et al., 2006; Chen et al., 2007; Stephen et al., 2007a; Stephen et al., 2007b), aberrant methylation of $C D K N 2 B$ has been implicated as an early event in the pathogenesis of these lesions. Preferential methylation of $C D K N 2 B$ has been shown to be a useful tumor marker in undifferentiated nasopharyngeal carcinoma (Wong et al., 2003). As a consistent target of aberrant promoter hypermethylation, $C D K N 2 B$ may serve as a useful biomarker and a potential therapeutic target for gene reactivation studies and in disease monitoring for progression.

The alteration of $R A R B$ via DNA hypermethylation has several implications in HNSCC. Decreased expression of $R A R B$ has been associated with increased keratinizing squamous differentiation in HNSCC cells (Wan et al., 1999). More importantly, in our primary HNSCC cohort (Chen et al., 2007), RARB silencing by promoter hypermethylation in early and late stage tumors suggest that DNA methylation of $R A R B$ is an early epigenetic event. Also, it has been demonstrated that the demethylating agent 5 -aza-CdR can restore $R A R B$ inducibility by retinoid ATRA (9-cis-RA) in most cell lines (Youssef et al., 2004).

\section{Conclusion}

HPV detection in saliva DNA shows promise as a non invasive approach for tumor HPV status within clearly defined parameters. Given the limited sample size of this study, for clinical relevance, the results will require confirmation and validation in larger cohorts. Pursuing the feasibility of detecting HPV and methylation markers in saliva DNA is relevant to not only early detection of HNSCC but also in disease monitoring in response to treatment as well as predictors of HNSCC especially in high risk individuals. Also, unlike genes that are inactivated by nucleotide sequence variation, genes silenced by epigenetic mechanisms are still intact and thus retain the potential to be reactivated by environmental or medical intervention (Olden, Issac, \& Roberts, 2011).

\section{Acknowledgements}

Drs. Stephen and Worsham had full access to all the data in the study and take responsibility for the integrity of the data and the accuracy of the data analysis. This study was supported by R01 NIH DE 15990 (Dr. Worsham).

\section{References}

American Cancer Society. (2012). Cancer Facts \& Figures 2012. Atlanta: American Cancer Society.

Ang, K. K., Harris, J., Wheeler, R., Weber, R., Rosenthal, D. I., Nguyen-Tan, P. F., ... Gillison, M. L. (2010). Human papillomavirus and survival of patients with oropharyngeal cancer. $N$ Engl J Med, 363(1), 24-35.

Belinsky, S. A., Liechty, K. C., Gentry, F. D., Wolf, H. J., Rogers, J., Vu, K., ... Byers, T. (2006). Promoter hypermethylation of multiple genes in sputum precedes lung cancer incidence in a high-risk cohort. Cancer Res, 66(6), 3338-3344. http://dx.doi.org/10.1158/0008-5472.CAN-05-3408

Brockstein, B., Haraf, D. J., Rademaker, A. W., Kies, M. S., Stenson, K. M., Rosen, F., ... Vokes, E. E. (2004). Patterns of failure, prognostic factors and survival in locoregionally advanced head and neck cancer treated with concomitant chemoradiotherapy: a 9-year, 337-patient, multi-institutional experience. Ann Oncol, 15(8), 1179-1186. http://dx.doi.org/10.1093/annonc/mdh308

Carvalho, A. L., Jeronimo, C., Kim, M. M., Henrique, R., Zhang, Z., Hoque, M. O., ... Califano, J. A. (2008). Evaluation of promoter hypermethylation detection in body fluids as a screening/diagnosis tool for head and neck squamous cell carcinoma. Clin Cancer Res, 14(1), 97-107. http://dx.doi.org/10.1158/1078-0432.CCR-07-0722

Carvalho, A. L., Henrique, R., Jeronimo, C., Nayak, C. S., Reddy, A. N., Hoque, M. O., .. Califano, J. A. (2011). Detection of promoter hypermethylation in salivary rinses as a biomarker for head and neck squamous cell $\begin{array}{lllll}\text { carcinoma surveillance. } \quad \text { Clin } & \text { Cancer }\end{array}$ http://dx.doi.org/10.1158/1078-0432.CCR-11-0324

Chen, A. A., Marsit, C. J., Christensen, B. C., Houseman, E. A., McClean, M. D., Smith, J. F., ... Kelsey, K. T. (2009). Genetic variation in the vitamin C transporter, SLC23A2, modifies the risk of HPV16-associated head and neck cancer. Carcinogenesis, 30(6), 977-981. 
Chen, K. M., Sawhney, R., Khan, M., Benninger, M. S., Hou, Z., Sethi, S., ... Worsham, M. J. (2007). Methylation of multiple genes as diagnostic and therapeutic markers in primary Head and Neck Squamous Cell Carcinoma. Arch Otolaryngol Head Neck Surg, 133(11), 1131-1138.

Chen, K. M., Stephen, J.K., Ghanem, T., Stachler, R., Gardner, G., Jones, L., ... Worsham, M. J. (2013). Human papilloma virus prevalence in a multiethnic screening population. Otolaryngol Head Neck Surg, 148(3), 436-442. http://dx.doi.org/10.1177/0194599812471938

Chuang, A. Y., Chuang, T. C., Chang, S., Zhou, S., Begum, S., Westra, W. H., ... Califano, J. A. (2008). Presence of HPV DNA in convalescent salivary rinses is an adverse prognostic marker in head and neck squamous cell carcinoma. Oral Oncol, 44(10), 915-919. http://dx.doi.org/10.1016/j.oraloncology.2008.01.001

Dayyani, F., Etzel, C. J., Liu, M., Ho, C. H., Lippman, S. M., \& Tsao, A. S. (2010). Meta-analysis of the impact of human papillomavirus (HPV) on cancer risk and overall survival in head and neck squamous cell carcinomas (HNSCC). Head Neck Oncol, 2(15), doi:1758-3284-2-15 [pii] 10.1186/1758-3284-2-15.

D'Souza, G., Kreimer, A. R., Viscidi, R., Pawlita, M., Fakhry, C., Koch, W. M., ... Gillison, M. L. (2007). Case-control study of human papillomavirus and oropharyngeal cancer. N Engl J Med, 356(19), 1944-1956.

Eads, C. A., Lord, R. V., Kurumboor, S. K., Wickramasinghe, K., Skinner, M. L., Long, T. I., ... Skinner, K. A. (2000). Fields of aberrant $\mathrm{CpG}$ island hypermethylation in Barrett's esophagus and associated adenocarcinoma. Cancer Res, 60(18), 5021-5026.

Fakhry, C., Westra, W. H., Li, S., Cmelak, A., Ridge, J. A., Pinto, H., ... Gillison, M. L. (2008). Improved survival of patients with human papillomavirus-positive head and neck squamous cell carcinoma in a prospective clinical trial. J Natl Cancer Inst, 100(4), 261-269. http://dx.doi.org/10.1093/jnci/djn011

Garcia, M., Derocq, D., Freiss, G., \& Rochefort, H. (1992). Activation of estrogen receptor transfected into a receptor-negative breast cancer cell line decreases the metastatic and invasive potential of the cells. Proc Natl Acad Sci U S A, 89(23), 11538-11542.

Gillison, M. L., Koch, W. M., Capone, R. B., Spafford, M., Westra, W. H., Wu, L., ... Sidransky, D. (2000). Evidence for a causal association between human papillomavirus and a subset of head and neck cancers. $J$ Natl Cancer Inst, 92(9), 709-720.

Gillison, M. L., \& Lowy, D. R. (2004a). A causal role for human papillomavirus in head and neck cancer. Lancet, 363(9420), 1488-1489. http://dx.doi.org/10.1016/S0140-6736(04)16194-1

Gillison, M. L. (2004b). Human papillomavirus-associated head and neck cancer is a distinct epidemiologic, $\begin{array}{lllll}\text { clinical, and molecular entity. Semin } & \text { Oncol, 31(6), }\end{array}$ http://dx.doi.org/10.1053/j.seminoncol.2004.09.011

Goessl, C., Muller, M., Straub, B., \& Miller, K. (2002). DNA alterations in body fluids as molecular tumor markers for urological malignancies. Eur Urol, 41(6), 668-676. http://dx.doi.org/10.1016/S0302-2838(02)00126-4

Gubanova, E., Brown, B., Ivanov, S. V., Helleday, T., Mills, G. B., Yarbrough, W. G., \& Issaeva, N. (2012). Downregulation of SMG-1 in HPV-positive head and neck squamous cell carcinoma due to promoter hypermethylation correlates with improved survival. Clin Cancer Res, 18(5), 1257-1267. http://dx.doi.org/10.1158/1078-0432.CCR-11-2058

Hafkamp, H. C., Speel, E. J., Haesevoets, A., Bot, F. J., Dinjens, W. N., Ramaekers, F. C., ... Manni, J. J. (2003). A subset of head and neck squamous cell carcinomas exhibits integration of HPV 16/18 DNA and overexpression of p16INK4A and p53 in the absence of mutations in p53 exons 5-8. Int J Cancer, 107(3), 394-400. http://dx.doi.org/10.1002/ijc.11389

Hoque, M. O., Begum, S., Topaloglu, O., Jeronimo, C., Mambo, E., Westra, W. H., ... Sidransky, D. (2004). Quantitative detection of promoter hypermethylation of multiple genes in the tumor, urine, and serum DNA of patients with renal cancer. Cancer Res, 64(15), 5511-5517. http://dx.doi.org/10.1158/0008-5472.CAN-04-0799

Hui, A. B., Lo, K. W., Kwong, J., Lam, E. C., Chan, S. Y., Chow, L. S., .. Huang, D. P. (2003). Epigenetic inactivation of TSLC1 gene in nasopharyngeal carcinoma. Mol Carcinog, 38(4), 170-178.

Issa, J. P., Ottaviano, Y. L., Celano, P., Hamilton, S. R., Davidson, N. E., \& Baylin, S. B. (1994). Methylation of the oestrogen receptor $\mathrm{CpG}$ island links ageing and neoplasia in human colon. Nat Genet, 7(4), 536-540.

Issa, J. P., Ahuja, N., Toyota, M., Bronner, M. P., \& Brentnall, T. A. (2001). Accelerated age-related CpG island 
methylation in ulcerative colitis. Cancer Res, 61, 3573-3577.

Ito, T., Shimada, Y., Hashimoto, Y., Kaganoi, J., Kan, T., Watanabe, G., ... Imamura, M. (2003). Involvement of TSLC1 in progression of esophageal squamous cell carcinoma. Cancer Res, 63(19), 6320-6326.

Kaur, J., Demokan, S., Tripathi, S. C., Macha, M. A., Begum, S., Califano, J. A., \& Ralhan, R. (2010). Promoter hypermethylation in Indian primary oral squamous cell carcinoma. Int $J$ Cancer, 127(10), 2367-2373. http://dx.doi.org/10.1002/ijc.25377

Kreimer, A. R., Clifford, G. M., Boyle, P., \& Franceschi, S. (2005). Human papillomavirus types in head and neck squamous cell carcinomas worldwide: a systematic review. Cancer Epidemiol Biomarkers Prev, 14(2), 467-475.

Kuramochi, M., Fukuhara, H., Nobukuni, T., Kanbe, T., Maruyama, T., Ghosh, H. P., .. Murakami, Y. (2001). TSLC1 is a tumor-suppressor gene in human non-small-cell lung cancer. Nat Genet, 27(4), 427-430.

Lee, A., Kim, Y., Han, K., Kang, C. S., Jeon, H. M., \& Shim, S. I. (2004). Detection of Tumor Markers Including Carcinoembryonic Antigen, APC, and Cyclin D2 in Fine-Needle Aspiration Fluid of Breast. Arch Pathol Lab Med, 128(11), 1251-1256.

Li, L. C., Chui, R., Nakajima, K., Oh, B. R., Au, H. C., \& Dahiya, R. (2000). Frequent methylation of estrogen receptor in prostate cancer: correlation with tumor progression. Cancer Res, 60, 702-706.

Licitra, L., Perrone, F., Bossi, P., Suardi, S., Mariani, L., Artusi, R., ... Pilotti, S. (2006). High-risk human papillomavirus affects prognosis in patients with surgically treated oropharyngeal squamous cell carcinoma. J Clin Oncol, 24(36), 5630-5636. http://dx.doi.org/10.1200/JCO.2005.04.6136

Maruya, S., Issa, J. P., Weber, R. S., Rosenthal, D. I., Haviland, J. C., Lotan, R., \& El-Naggar, A. K. (2004). Differential methylation status of tumor-associated genes in head and neck squamous carcinoma: incidence and potential implications. Clin Cancer Res, 10(11), 3825-3830. http://dx.doi.org/10.1158/1078-0432.CCR-03-0370

Munger, K., Baldwin, A., Edwards, K. M., Hayakawa, H., Nguyen, C. L., Owens, M., ... Huh, K. (2004). Mechanisms of human papillomavirus-induced oncogenesis. $J$ Virol, 78(21), 11451-11460. http://dx.doi.org/10.1128/JVI.78.21.11451-11460.2004

Murakami, Y., Nobukuni, T., Tamura, K., Maruyama, T., Sekiya, T., Arai, Y., ... Reeves, R. H. (1998). Localization of tumor suppressor activity important in nonsmall cell lung carcinoma on chromosome 11q. Proc Natl Acad Sci U S A, 95(14), 8153-8158.

Olden, K., Isaac, L., \& Roberts, L. (2011). Neighborhood-specific epigenome analysis: the pathway forward to understanding gene-environment interactions. NC Med J, 72(2), 125-127.

Palmisano, W. A., Divine, K. K., Saccomanno, G., Gilliland, F. D., Baylin, S. B., Herman, J. G., \& Belinsky, S. A. (2000). Predicting lung cancer by detecting aberrant promoter methylation in sputum. Cancer Res, 60(21), 5954-5958.

Ponglikitmongkol, M., Green, S., \& Chambon, P. (1988). Genomic organization of the human oestrogen receptor gene. Embo J, 7(11), 3385-3388.

Post, W. S., Goldschmidt-Clermont, P. J., Wilhide, C. C., Heldman, A. W., Sussman, M. S., Ouyang, P., ... Issa, J. P. (1999). Methylation of the estrogen receptor gene is associated with aging and atherosclerosis in the cardiovascular system. Cardiovasc Res, 43, 985-991.

Ragin, C. C., Taioli, E., Weissfeld, J. L., White, J. S., Rossie, K. M., Modugno, F., \& Gollin, S. M. (2006). 11q13 amplification status and human papillomavirus in relation to p16 expression defines two distinct etiologies of head and neck tumours. Br J Cancer, 95(10), 1432-1438. http://dx.doi.org/10.1038/sj.bjc.6603394

Raju, U., Mei, L., Seema, S., Hina, Q., Wolman, S. R., \& Worsham, M. J. (2006). Molecular classification of breast carcinoma in situ. Curr Genomics, 7, 523-532. http://dx.doi.org/10.2174/138920206779315719

Rettori, M. M., de Carvalho, A. C., Bomfim Longo, A. L., de Oliveira, C. Z., Kowalski, L. P., Carvalho, A. L., Vettore, A. L. (2013). Prognostic significance of TIMP3 hypermethylation in post-treatment salivary rinse from head and neck squamous cell carcinoma patients. Carcinogenesis, 34(1), 20-27. http://dx.doi.org/10.1093/carcin/bgs311

Sankaranarayanan, R., Budukh, A. M., \& Rajkumar, R. (2001). Effective screening programmes for cervical cancer in low- and middle-income developing countries. Bull World Health Organ, 79(10), 954-962. 
Scheffner, M., Werness, B. A., Huibregtse, J. M., Levine, A. J., \& Howley, P. M. (1990). The E6 oncoprotein encoded by human papillomavirus types 16 and 18 promotes the degradation of p53. Cell, 63(6), 1129-1136. http://dx.doi.org/10.1016/0092-8674(90)90409-8

Schouten, J. P., McElgunn, C. J., Waaijer, R., Zwijnenburg, D., Diepvens, F., \& Pals, G. (2002). Relative quantification of 40 nucleic acid sequences by multiplex ligation-dependent probe amplification. Nucleic Acids Res, 30(12), e57

Schwartz, S. R., Yueh, B., McDougall, J. K., Daling, J. R., \& Schwartz, S. M. (2001). Human papillomavirus infection and survival in oral squamous cell cancer: a population-based study. Otolaryngol Head Neck Surg, 125(1), 1-9. http://dx.doi.org/10.1067/mhn.2001.116979

Sethi, S., Benninger, M. S., Lu, M., Havard, S., \& Worsham, M. J. (2009). Noninvasive molecular detection of head and neck squamous cell carcinoma: an exploratory analysis. Diagn Mol Pathol, 18(2), 81-87. http://dx.doi.org/10.1097/PDM.0b013e3181804b82

Shintani, S., Nakahara, Y., Mihara, M., Ueyama, Y., \& Matsumura, T. (2001). Inactivation of the p14(ARF), $\mathrm{p} 15(\mathrm{INK} 4 \mathrm{~B})$ and p16(INK4A) genes is a frequent event in human oral squamous cell carcinomas. Oral Oncol, 37(6), 498-504.

Slebos, R. J., Yi, Y., Ely, K., Carter, J., Evjen, A., Zhang, X., ... Chung, C. H. (2006). Gene expression differences associated with human papillomavirus status in head and neck squamous cell carcinoma. Clin Cancer Res, 12(3 Pt 1), 701-709. http://dx.doi.org/10.1158/1078-0432.CCR-05-2017

Smith, E. M., Ritchie, J. M., Summersgill, K. F., Hoffman, H. T., Wang, D. H., Haugen, T. H., \& Turek, L. P. (2004). Human papillomavirus in oral exfoliated cells and risk of head and neck cancer. J Natl Cancer Inst, 96(6), 449-455.

Smith, E. M., Wang, D., Kim, Y., Rubenstein, L. M., Lee, J. H., Haugen, T. H., \& Turek, L. P. (2008). P16INK4a expression, human papillomavirus, and survival in head and neck cancer. Oral Oncol, 44(2), 133-142. http://dx.doi.org/10.1016/j.oraloncology.2007.01.010

Speight, P. M., Palmer, S., Moles, D. R., Downer, M. C., Smith, D. H., Henriksson, M., \& Augustovski, F. (2006). The cost-effectiveness of screening for oral cancer in primary care. Health Technol Assess, 10(14), 1-144, iii-iv.

Steenbergen, R. D., Kramer, D., Braakhuis, B. J., Stern, P. L., Verheijen, R. H., Meijer, C. J., \& Snijders, P. J. (2004). TSLC1 gene silencing in cervical cancer cell lines and cervical neoplasia. J Natl Cancer Inst, 96(4), 294-305.

Stephen, J. K., Vaught, L. E., Chen, K. M., Sethi, S., Shah, V., Benninger, M. S., ... Worsham, M. J. (2007a). Epigenetic events underlie the pathogenesis of sinonasal papillomas. Mod Pathol, 20(10), 1019-1027.

Stephen, J. K., Vaught, L. E., Chen, K. M., Shah, V., Schweitzer, V. G., Gardner, G., ... Worsham, M. J. (2007b). An epigenetically derived monoclonal origin for recurrent respiratory papillomatosis. Arch Otolaryngol Head Neck Surg, 133(7), 684-692.

Stephen, J. K., Chen, K. M., Shah, V., Havard, S., Kapke, A., Lu, M., Benninger, M. S., \& Worsham, M. J. (2010). DNA hypermethylation markers of poor outcome in laryngeal cancer. Clin Epigenetics, 1(1-2), 61-69. http://dx.doi.org/10.1007/s13148-010-0005-3

Stephen, J. K., Chen, K. M., Shah, V., Havard, S., Lu, M., Schweitzer, V. P., ... Worsham, M. J. (2012). Human papillomavirus outcomes in an access-to-care laryngeal cancer cohort. Otolaryngol Head Neck Surg, 146(5), 730-738. http://dx.doi.org/10.1177/0194599811434482

Stephen, J. K., Divine, G., Chen, K. M., Chitale, D., Havard, S., \& Worsham, M. J. (2013). Significance of p16 in Site-specific HPV Positive and HPV Negative Head and Neck Squamous Cell Carcinoma. Cancer and Clinical Oncology, 2(1), 51-61.

Sun, W., Zaboli, D., Wang, H., Liu, Y., Arnaoutakis, D., Khan, T., ... Califano, J. A. (2012). Detection of TIMP3 promoter hypermethylation in salivary rinse as an independent predictor of local recurrence-free survival in head and neck cancer. Clin Cancer Res, 18(4), 1082-1091. http://dx.doi.org/10.1158/1078-0432.CCR-11-2392

Wan, H., Oridate, N., Lotan, D., Hong, W. K., \& Lotan, R. (1999). Overexpression of retinoic acid receptor beta in head and neck squamous cell carcinoma cells increases their sensitivity to retinoid-induced suppression of squamous differentiation by retinoids. Cancer Res, 59(14), 3518-3526. 
Weinberger, P. M., Yu, Z., Haffty, B. G., Kowalski, D., Harigopal, M., Brandsma, J., ... Psyrri, A. (2006). Molecular classification identifies a subset of human papillomavirus--associated oropharyngeal cancers with favorable prognosis. J Clin Oncol, 24(5), 736-747. http://dx.doi.org/10.1200/JCO.2004.00.3335

Wong, T. S., Tang, K. C., Kwong, D. L., Sham, J. S., Wei, W. I., Kwong, Y. L., \& Yuen, A. P. (2003). Differential gene methylation in undifferentiated nasopharyngeal carcinoma. Int J Oncol, 22(4), 869-874.

Worsham, M. J., Pals, G., Schouten, J. P., Van Spaendonk, R. M., Concus, A., Carey, T. E., \& Benninger, M. S. (2003). Delineating genetic pathways of disease progression in head and neck squamous cell carcinoma. Arch Otolaryngol Head Neck Surg, 129(7), 702-708.

Worsham, M. J., Chen, K. M., Meduri, V., Nygren, A. O., Errami, A., Schouten, J. P., \& Benninger, M. S. (2006a). Epigenetic events of disease progression in head and neck squamous cell carcinoma. Arch Otolaryngol Head Neck Surg, 132(6), 668-677.

Worsham, M. J., Chen, K. M., Tiwari, N., Pals, G., Schouten, J. P., Sethi, S., \& Benninger, M. S. (2006b). Fine-mapping loss of gene architecture at the CDKN2B (p15INK4b), CDKN2A (p14ARF, p16INK4a), and MTAP genes in head and neck squamous cell carcinoma. Arch Otolaryngol Head Neck Surg, 132(4), 409-415.

Worsham, M. J., Chen, K. M., Ghanem, T., Stephen, J. K., \& Divine, G. (2013a). Epigenetic Modulation of Signal Transduction Pathways in HPV-Associated HNSCC. Otolaryngol Head Neck Surg. http://dx.doi.org/10.1177/0194599813490895

Worsham, M. J., Stephen, J. K., Chen, K. M., Mahan, M., Schweitzer, V. P., Havard, S., \& Divine, G. (2013b). Improved survival with HPV among African Americans with oropharyngeal cancer. Clin Cancer Res. http://dx.doi.org/10.1158/1078-0432.CCR-12-3003

Yeh, K. T., Chang, J. G., Lin, T. H., Wang, Y. F., Tien, N., Chang, J. Y., ... Shih, M. C. (2003). Epigenetic changes of tumor suppressor genes, P15, P16, VHL and P53 in oral cancer. Oncol Rep, 10(3), 659-663.

Youssef, E. M., Lotan, D., Issa, J. P., Wakasa, K., Fan, Y. H., Mao, L., ... Lotan, R. (2004). Hypermethylation of the retinoic acid receptor-beta(2) gene in head and neck carcinogenesis. Clin Cancer Res, 10(5), 1733-1742.

Zhao, M., Rosenbaum, E., Carvalho, A. L., Koch, W., Jiang, W., Sidransky, D., \& Califano, J. (2005). Feasibility of quantitative PCR-based saliva rinse screening of HPV for head and neck cancer. Int J Cancer, 117(4), 605-610. 


\section{Supplement}

Supplemental Table 1. Cohort Site, HPV and Methylation status

\begin{tabular}{|c|c|c|c|c|c|c|c|c|c|c|c|c|c|c|c|c|c|c|c|c|c|c|c|}
\hline ID & Site & $\begin{array}{l}\text { qPCR } \\
\text { HPV16 }\end{array}$ & $\begin{array}{l}\text { TIM } \\
P 3 \\
\end{array}$ & $\begin{array}{l}A P \\
C \\
\end{array}$ & $\begin{array}{l}C D K \\
N 2 A \\
\end{array}$ & $\begin{array}{l}R A \\
R B \\
\end{array}$ & $\begin{array}{l}C D K \\
N 2 B \\
\end{array}$ & $\begin{array}{l}\mathrm{HI} \\
\mathrm{Cl} \\
\end{array}$ & $\begin{array}{l}\mathrm{CH} \\
\mathrm{FR} \quad \delta \\
\end{array}$ & $\begin{array}{l}\text { CASP } \\
8 \\
\end{array}$ & $\begin{array}{l}C D K \\
N 1 B \\
\end{array}$ & $\begin{array}{l}P T \\
E N \\
\end{array}$ & $\begin{array}{l}C D \\
44 \\
\end{array}$ & $\begin{array}{l}\text { RASS } \\
F 1 \\
\end{array}$ & $\begin{array}{l}D A P \\
K 1 \\
\end{array}$ & $\begin{array}{l}V H \\
L \\
\end{array}$ & $\begin{array}{l}E S \\
R 1\end{array}$ & $\begin{array}{l}\text { RASS } \\
F 1 \\
\end{array}$ & $\begin{array}{l}P \\
73 \\
\end{array}$ & $\begin{array}{l}F H \\
I T\end{array}$ & $\begin{array}{l}I G S \\
F 4 \\
\end{array}$ & $\begin{array}{l}\mathrm{CDH} \\
13\end{array}$ & $\begin{array}{l}\text { GST } \\
P 1 \\
\end{array}$ \\
\hline $\mathrm{S} 1$ & $\mathrm{OC}$ & Negative & & & & & & & & & & & & & & & & & & & & & \\
\hline $\mathrm{T} 1$ & & Negative & & $\mathbf{M}$ & & M & & & & & & & & $\mathbf{M}$ & & & & $\mathbf{M}$ & & & & & \\
\hline S2 & Other-NeckMass & Negative & & & & & & & & & & & & & & & & & & & & & \\
\hline $\mathrm{T} 2$ & & Negative & & & & $\mathbf{M}$ & & & & $\mathbf{M}$ & & & & & & & & & & & & & \\
\hline $\mathrm{S} 3$ & $\mathrm{OC}$ & Negative & & & & & & & & & & & & & & & & & & & & & \\
\hline $\mathrm{T} 3$ & & No result & & & & & & & & & & & & & & & & & & & & & \\
\hline S4 & Other-skin upper lip & Negative & & & & & & & & & & & & & & & & & & & & & \\
\hline T4 & & Negative & & & & & & & & & & & & & & & & & & & & & \\
\hline S5 & $\mathrm{OP}$ & Negative & & & & & & & & & & & & & & & & & & & & & \\
\hline T5 & & Negative & & & & & & & & & & & & & & & & & & & & & \\
\hline S6 & $\mathrm{OP}$ & Positive & & & & & & & & & & & & & & & & & & & & & \\
\hline T6 & & Positive & & M & & & & & M & & & & & & & & & & & & & & \\
\hline S7 & HP & Negative & & & & & & & & & & & & & & & & & & & & & \\
\hline $\mathrm{T} 7$ & & Negative & $\mathbf{M}$ & M & & & & & & & M & & & & & & & & & & & M & M \\
\hline S8 & Larynx & Negative & $\mathbf{M}$ & $\mathbf{M}$ & & & & & & & & & & & & & & & & & & & \\
\hline $\mathrm{T} 8$ & & Negative & & & & & & & & & & & & & & & & & & & & & \\
\hline S9 & $\mathrm{OC}$ & Negative & & & & & & & & & & & & & & & & & & & & & \\
\hline T9 & & No result & $\mathbf{M}$ & & & & & & & & & & & & & & & & & & & & \\
\hline $\mathrm{S} 10$ & Larynx & Negative & & & & & & & & & & & & & & & & & & & & & \\
\hline $\mathrm{T} 10$ & & Negative & & & & $\mathbf{M}$ & & & & & & & & & & & & & & & & & \\
\hline S11 & OP & Negative & & & & & & & & & & & & & & & & & & & & & \\
\hline $\mathrm{T} 11$ & & Negative & & & & & & & & & & & & & & & & & & & & & \\
\hline $\mathrm{S} 12$ & HP & Negative & & & & & & & & & & & & & & & & & & & & & \\
\hline $\mathrm{T} 12$ & & No result & & & & & $\mathbf{M}$ & & $\mathbf{M}$ & & & & & & & & & & & & & & \\
\hline $\mathrm{S} 13$ & Larynx & Negative & & & & & & & & & & & & & & & & & & & & & \\
\hline $\mathrm{T} 13$ & & Positive & $\mathbf{M}$ & & & M & M & & & & & & & & M & & & & & & & & \\
\hline S14 & HP & Negative & & & & & $\mathbf{M}$ & & & & & & & & & & & & & & & & \\
\hline T14 & & Negative & & & & & & & $\mathbf{M}$ & & & & & & & & & & & & & & \\
\hline S15 & OP & Negative & & & & & & & & & & & & & & & & & & & & & \\
\hline $\mathrm{T} 15$ & & Negative & & & & & & & & & & & & & & & & & & & & & \\
\hline S16 & Larynx & Negative & & & & & & & & & & & & & & & & & & & & & \\
\hline T16 & & Positive & & & & & & & & & & & & & & & & & & & & & \\
\hline S17 & Larynx & Negative & & & & & & & & & & & & & & & & & & & & & \\
\hline $\mathrm{T} 17$ & & Negative & & & & & & & & & & & & & & & & & & & & & \\
\hline $\mathrm{S} 18$ & OP & Positive & & & & & & & & & & & & & & & & & & & & & \\
\hline $\mathrm{T} 18$ & & Positive & & & & & & & & & & & & & $\mathbf{M}$ & & & & & & $\mathbf{M}$ & $\mathbf{M}$ & \\
\hline S19 & Other-Neck mass & Negative & & & & & & & & & & & & & & & & & & & & & \\
\hline T19 & & Positive & & & & $\mathbf{M}$ & $\mathbf{M}$ & & & & & & & & & & & & & & & & \\
\hline S20 & $\mathrm{OC}$ & Negative & & & & & & & & & & & & & & & & & & & & & \\
\hline $\mathrm{T} 20$ & & Negative & & & & & & & & & & & & & & & & & & & & & \\
\hline S22 & $\mathrm{OP}$ & Positive & & & & & & & & & & & & & & & & & & & & & \\
\hline $\mathrm{T} 22$ & & Positive & $\mathbf{M}$ & & & $\mathbf{M}$ & & & & & & & & & & & & & & & & & \\
\hline S24 & Larynx & Negative & & & & & & & & & & & & & & & & & & & & & \\
\hline $\mathrm{T} 24$ & & Positive & & & $\mathbf{M}$ & & $\mathbf{M}$ & & & & $\mathbf{M}$ & & & & & $\mathbf{M}$ & & $\mathbf{M}$ & $\mathbf{M}$ & $\mathbf{M}$ & $\mathbf{M}$ & $\mathbf{M}$ & $\mathbf{M}$ \\
\hline S25 & Other-Neck mass & Negative & & & & & & $\mathbf{M}$ & & & & $\mathbf{M}$ & $\mathbf{M}$ & & & & $\mathbf{M}$ & & & & & & $\mathbf{M}$ \\
\hline $\mathrm{T} 25$ & & Positive & & & & $\mathbf{M}$ & & & & & & & & & & & & & & & & & \\
\hline S27 & Larynx & Negative & & & & & & & & & & & & & & & & & & & & & \\
\hline $\mathrm{T} 27$ & & Positive & & & & & & & & & & & & & & & & & & & $\mathbf{M}$ & & \\
\hline S29 & Larynx & Negative & & & & & & & & & & & & & & & & & & & & & \\
\hline T29 & & Negative & & $\mathbf{M}$ & $\mathbf{M}$ & & & & & & & & & & & & & & & & & & \\
\hline $\mathrm{S} 30$ & Larynx & Negative & & & & & & & & & & & & & & & & & & & & & \\
\hline $\mathrm{T} 30$ & & Negative & $\mathbf{M}$ & & & & & & & & & & & & & & & & & & & & \\
\hline $\mathrm{S} 31$ & Larynx & Negative & & $\mathbf{M}$ & $\mathbf{M}$ & & & & & & & & & & & & & & & & & & \\
\hline $\mathrm{T} 31$ & & Negative & & $\mathbf{M}$ & & $\mathbf{M}$ & & & & & & & & & $\mathbf{M}$ & & & & & & & & \\
\hline S32 & Other-Nasopharynx & Positive & & & & & & & & & & & & & & & & & & & & & \\
\hline $\mathrm{T} 32$ & & Positive & & & & & & & & & & & & & & & & & & & & & \\
\hline S33 & Larynx & Negative & & & & & & & & & & & & & & & & & & & & & \\
\hline $\mathrm{T} 33$ & & Negative & $\mathbf{M}$ & $\mathbf{M}$ & $\mathbf{M}$ & & $\mathbf{M}$ & & & & & & & & & & $\mathbf{M}$ & & & & & & \\
\hline S34 & Larynx & Positive & & & & & & & & & & & & & & & & & & & & & \\
\hline $\mathrm{T} 34$ & & Positive & & & & & & & & & & & & & & & & & & & & & \\
\hline S56 & HP & Negative & & & & & & & & & & & & & & & & & & & & & \\
\hline T56 & & No result & & $\mathbf{M}$ & & & M & & & & & & & & & & & & & & & $\mathbf{M}$ & \\
\hline
\end{tabular}




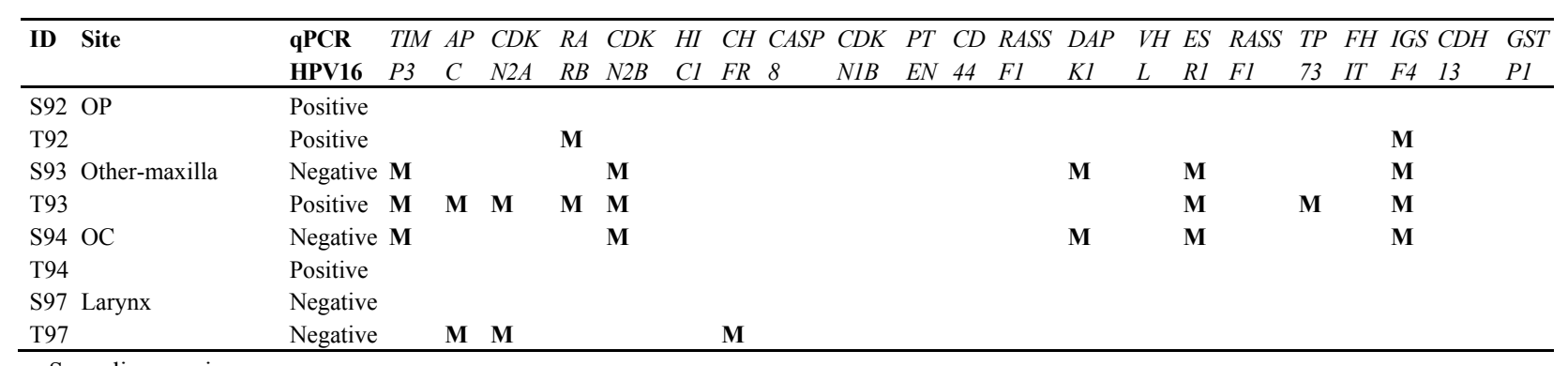

$\mathrm{S}=$ saliva specimens

$\mathrm{T}=$ tumor specimens

$\mathrm{OC}=$ Oral Cavity

$\mathrm{OP}=$ Oropharynx

$\mathrm{HP}=$ Hypopharyn $\mathrm{x}$

$\mathrm{M}=$ Methylated genes

\section{Copyrights}

Copyright for this article is retained by the author(s), with first publication rights granted to the journal.

This is an open-access article distributed under the terms and conditions of the Creative Commons Attribution license (http://creativecommons.org/licenses/by/3.0/). 